\title{
2 枚の薄板によるパネルの構法計画
}

\author{
面部品の開 発研究
}

$\begin{array}{lllll}\text { 正会員 } & \text { 井 } & \text { 口 } & \text { 洋 } & \text { 佑*1 } \\ \text { 正会員 } & \text { 鈴 } & \text { 木 } & \text { 清 } & \text { 丈*2 } \\ \text { 正会員 } & \text { 遠 } & \text { 藤 } & \text { 博 } & \text { 隆*3 }\end{array}$

\section{1. 研哭目的}

$1 つ の$ 建物について考えて見ると，その中で最も多い 部位注面部位である。従って当然, 現在の工業化建築に 於ては, 壁・床・屋根等の面部分には, 種々の面部品が 多量に使用されている。しかし，工慈生産のメリットや 品質の安定性，さらに工業生産に適した製造法を用いて いるか，と言う面から見ると，現在の面部品は必ずしも 満足出来るものではなく，工業化建築に適した面部品が

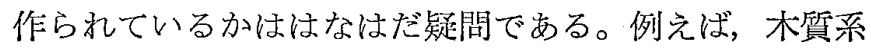
パネル・鉄鋼系パネルのように，パネルの組み立て部材 種が多く，そのアッセンブル工程も複雑なもの，又，鉄 筋コンクリート系パネルのように，部材種は少ないが, その量産スピードや量産規模に限度があるものなど, 種 ↔の問題点が指摘される。さらに最近では，工業化建築 特にプレファブ住宅のコスト・ダウン化, 品質の安定化 が社会的に要求されてきている。

以上のよらな状態に抒いては，建物の中で最も大量に 利用さている面部品の根本的な改良や開発を拔きにし て, 問題解決の糸口を見つけることは困難と言える。従 って，面部品の組み立て部材種が少なく，そのアッセン ブル工程む単純で，かつ品質が安定していて，面部品自 体の信頼性も高く，さらに飛躍的に高度な工業生産によ る量産が可能と言ったように，今までの面部品の工業生 産上の問題点を解消した面部品の開発・研究が急務と言 える。

本研究では，現在までに製品化された面部品に対する 上記のような批判に基づいて，次項で示寸開発目標及び 設計条件の設定を行った。そして [図一-1］に示発想に 従って，その設計条件に対的解答を求めた。又，その 発想の原理にも着目しその解明を行ない，さらにその原 理に基づく「2 枚の薄板によるパネルの棈法計画」を, 展開させた。

本論文では以上の内「原理の解明，及び原理の展開」

*1 巢京理科大学 教授・工博

*2 東京理科大学 大学院生

*3 東京理科大学 大学院生

(昭和 53 年 8 月 24 日本稿受理 ・討論期限炤和 55 年 3 月末日)
の部分を中心に述べることとする。

\section{2. 開発目標}

我々はこの開発に当り, 目標として以下に示す 4 点を 設定した。

（1）その生産過程において, 高速の工業生産が可能 であること。(これは目標の中で最も重要な点であり，今 後の工業化建築の部品として考えた場合, 不可欠の目標 である。)

（2）薄板を厚みのあるパネルに構成し, 形状的に最 も效率が高く，丈夫なパネルを設計すること。(薄板を用 いることにより，パネルの軽量化が可能となり, 又要求 に応じてスキマに断熱材, 遮音材等を自由に入れること も可能となる。)

（3）パネル 表面が平坦であること。（使用時には当 然，パネル表面に仕上げ材等を貼ることが予想される。 その為, 仕上げ材の貼付が可能となるようにパネル表面 を平坦にしておく必要がある。)

（4）端部見切りが容易であること。(工業生産上，エ ンドレス生産の手法が侾えられるが，これを可能にする 為に端部の形状が切断可能なものであること。)

\section{3. 設計条件}

上で述べた目標を具体化する方法として，以下に示す 設計条件を設定した。

（a） 2 枚の薄板を用いて厚みの西るパネルを作る。 （薄板を “2 枚”用いることにより，1 枚でパネルを作る 場合と比較し, 複雑な折り曲げ加工を省くことが出来高 度な工業生産が可能になり易い1。)

（b）薄板を波状や凹凹状（デッキ・プレート状等） に成形しない。(外形寸法に変化が生じない為, 工業生産 化が大変容易となる。と同時に表面をフラットにするこ とも出来る。)

（c）加工は切り込み及びプレスによる工業化量産加 工を用いる。(切り込み加工, プレス加工, 共に 1 工程で すむようにする。)

（d）部材（2 枍の薄板）どうしの接合は, 同質一種 の接着加工を用いる。(例えば,スポット・ウェルド等が 
考えられる。この為，溶接棒等が使用出来るか否かも考 慮に入れた。)

\section{4. パネルの構法計画原理 (厚みの出し方) ${ }^{2)}$}

2 枚の薄板から厚夕のあるパネルを作り出す場合，大 きく見ると下図 [図一1，図一2］に示す 2 種の方法が考 えられる。

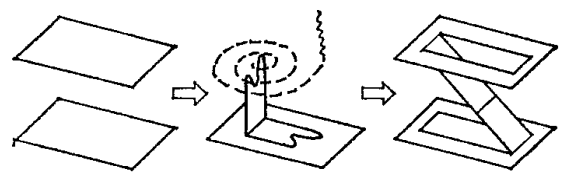

图一1 構法計画原理（1）

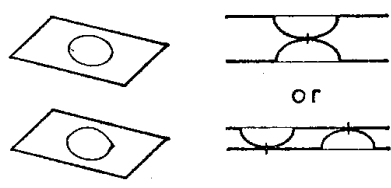

図一2 構法計画原理（2）

図一1に示寸方法はそれぞれの薄板に切り込みを入 れ，それを折り曲げ，それらを組み合わせることによっ て厚みを出寸方法である。

図一2 に示す方法はそれぞれの薄板に切り込みを入れ ずプレス加工を行ない，突起を作り，それを利用するこ とによって厚みを出す方法である。

以上 2 種の内, 本研究では, 図一1 の原理に基づくパ ネル構法を研究対象とした。

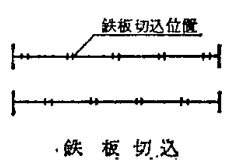

$\Omega$
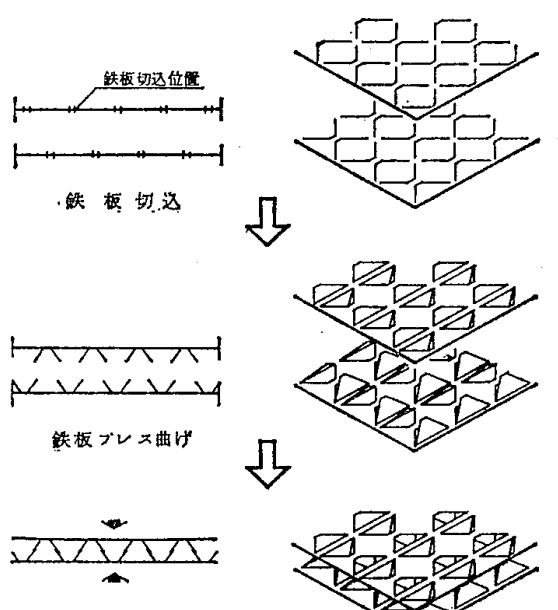

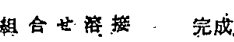

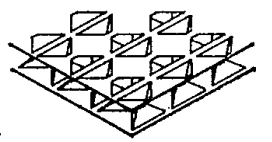

図一3 加工組立原理
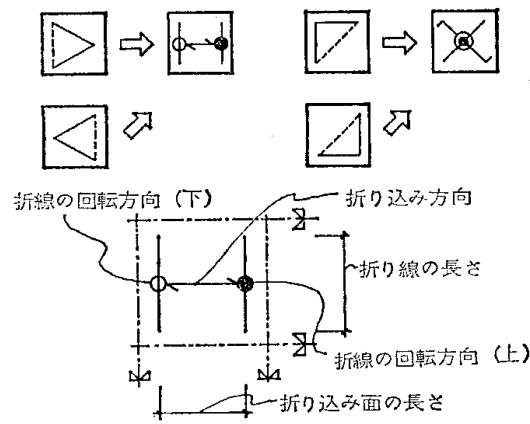

図一4 パターンの抽象化

\section{5. 記 号 化}

パターンの抽象化を提案した。(図一4 参照)

6. 1 次ユニッドの考え方

「3. パネルの構法計画原理」の所で述べた原理に基ら゙ いて，面部品を作るのには「1次ユニット」の考え方が 必要になる。そこでこの1次ユニットを考える際，基本 的に考えておかなければならないことを以下に示す。

（1）連続性があること。

同じ形の 1 次ユニットを隚間なく連続して述べ，無限 に大きな平面を作ることが可能でなければならない。穴 の為には縦・横 (斜) 両方向に連続性がなければならな い。よって，外形を正方形か正三角形（実際はひし形と 見る方が良い）にすると都合が良い。

（2）その部分のみで厚みが出せること。

同じ形を連続させる場合のみ考え るので，その部分だけで厚みを出せ ることが必要となる。(4.パネルの 構法計画原理＼cjkstart参照）この為右図の ような場合正三角形では 1 次ユニッ トに成り得ず，ひし形の 1 次ユニッ

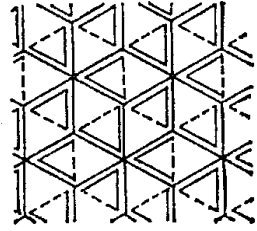

図 -5
トと考えなければならない。

(3) 上下同形であること。

面部品製作の連続性から言って，1次ユニット（特に 外形）は上下 (表裹) 同形でなければならない。なぜな ら，1 次ユニット端部が凸凹になり見切りが覀くなるか らである。

（4）端部に耳があること。

端部見切りをうまく行うために注，「上下同形」だけ で注不十分で, 端部に耳が必要である。

（5）切り达み穴から溶接棒等が入ること。

\section{1 次ユニット}

1 次ユニットに於ては,

（a）重㸚合わせの原則

(b) 折り曲げ線と折り曲げ方向の原則

の 2 つの原則がある。

「а。重社合わせの原則」とは，上下 2 枚の薄板加ら折

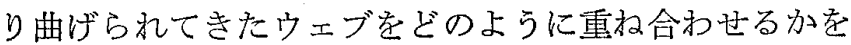
意味し，下図 (図一6)に示すような多くの方法が考えら れる。

（イ）（口）は原理的にも，部品的にも全く同じもので 共に可能であるが，今回は工業生産技術等に於ける組み 立てやすさを考光，(口）除外しに。（ハ（二）の両夕 イプはいずれもプレス加工の段階で $90^{\circ}$ 以上出げる必要 があること，又溶接棒等の捚入に問題があること，さら に（二のタイプは原則にも反していることから共に除 外した。（ホ）(ヘ）のタイプは（イ（口）と同椂に全く 同じであるので（木）を代表とした。（ト）は上下 2 枚の 薄板を接合する際，溶接棒等を上下加ら捙入出来ず問題 


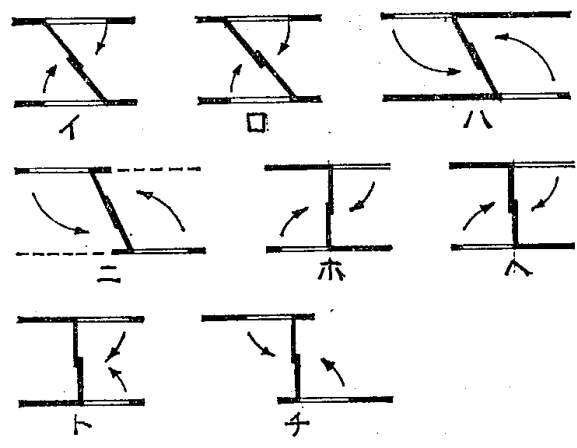

図一6 重放合わせの原理

があるため除外した。以上の結果，今回は（イ）(ホ）の 2 種のタイイプ限定することとした。

$\ulcorner\mathrm{b}$ 折り曲げ線と折り曲げ方向の原則」とは，上下 2 枚の薄板からウェブ部分を作るのに，どの部分をどのよ らに曲げれば良いかを意味し，これは大きく 2 種に分け られる。それは曲げ線が 1 次ユニットの外形線と同じ方 向の場合と，そうでない場合の 2 種である。
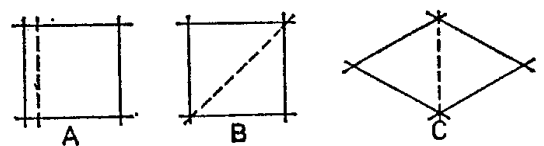

図一7 折り曲げ線と折り曲げ方向の原理

平行な場合とは，図一7(A)のような場合で，この 1 次ニニットを組み合わせるためには，外形が正方形か長 方形のような平行線を持つものでなければならない。も う一つの平行でない場合とは，(B) (C)の上らな場合で これには折り曲げ線が詨角線と平行でなければならない という条件が当然ついてくる。(同じ形を上下に用いる という条件より。)

以上，条件と成り得る多くのことを述べてきたが，こ れらを満たす 1 次ユニットとしては，正方形かひし形 (正三角形) が非常に都合が良い。そこで今あげた 2 種 類について実際に考えてみると，図一8に示すようにな る。

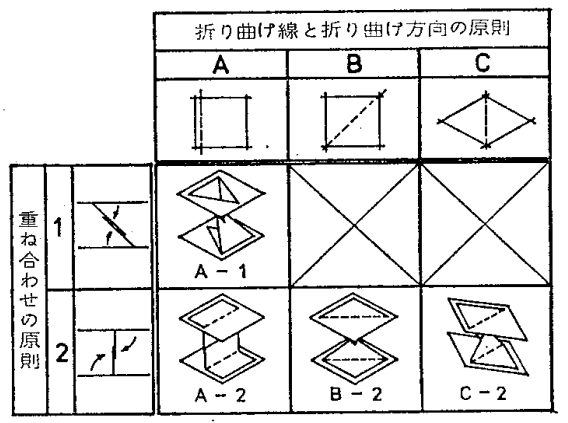

図一81次ユニット原理の組み合わせ

上図に示した 1 次ユニットの切り込み形状は単なる一 例にすぎず，下図 (図一9) に示すようにどのような形状 でも可能である。しかし，本論文では (A-1) (B-2) (C2）の3 種の切込形状をとりあげた。气がりうる切込 形状は下記に例示すると抢りである。

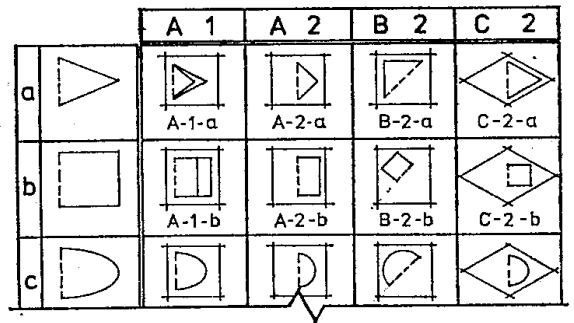

图一9切り込み形状

* 例外……右図に示すパターンは (A-1-a) と非常に類似した形状をし ているが，大きく異なる点がある。 それは 1 次ニニットが矩形をしてい ない点でする。この為, 長方形パネ ルの製作に問題が生じる。

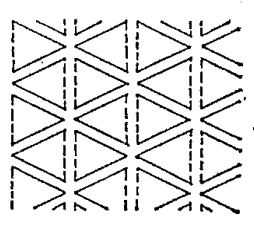

図-10
8. パターンの抽出

\section{（1） $\triangle$ 型について}

この1次ユニットを並べていけばパネルが出来るわけ であるが，これには 2 種の基本グリッドが考えられる。 （但し，1，上下が全く重祀ること。2，スキマなく並べ ること。)
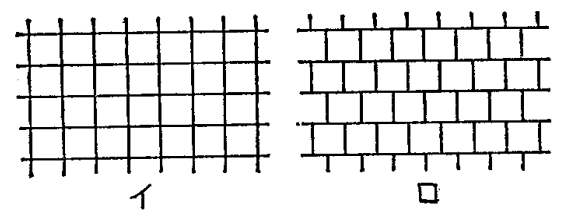

図一11 基本グリット

（イ）（口）の2種が考えられるが，（口）はその連続性 が一方向であるため端部見切りがうまくいかない。そこ で（イ）のみとした。

白黒の碁石を規則に並べるパターンが 2 進法原理から 無限に存在するように，1 次ユニットを基本グリッド上 に自由に配列すると，無限の薄板スラブが作れると予想 される。しかし建築構法, 部品生産構法の立場から見る と，より単純な規則性に基づいて出来ているものが，製 造上，コスト上など生産面から有利である。そこで，力 学的合理性等から判断して重要と思わ机るウェブの通り 方に着目して，代表的パターンを抽出することを考え た。そこでウェブの通り方を葬える上で最低の連続つま

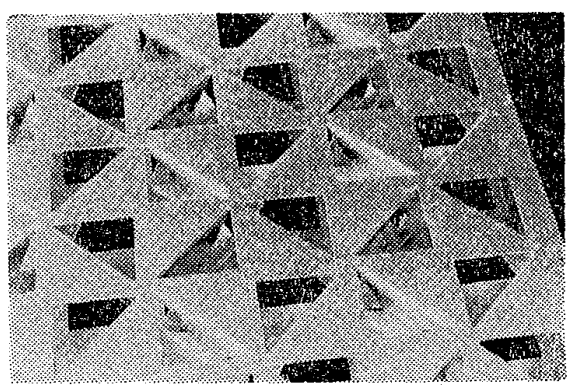

写真-1 


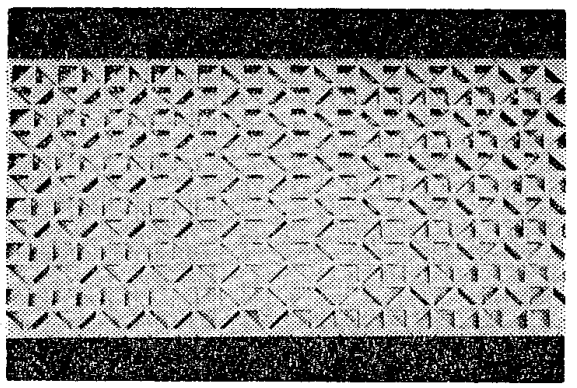

写真一2

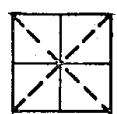

A

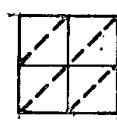

$\mathrm{B}$

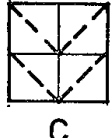

図一12 ウェブの通り方

り 1 次ユニット4個を1つの「2次ユニット」 として 考えた。2 次ニニットのウェブの通り方には，図一12 に示す 3 種がある。

(A) はウェブが斜 2 方向に通っているもので，方向性 が無い。(B) は斜 1 少向に通っているもので方向性が有 る。（C）はウェブがジグザグに通っているものである。 これらの具体的パターンは下図に示子 13 種である。

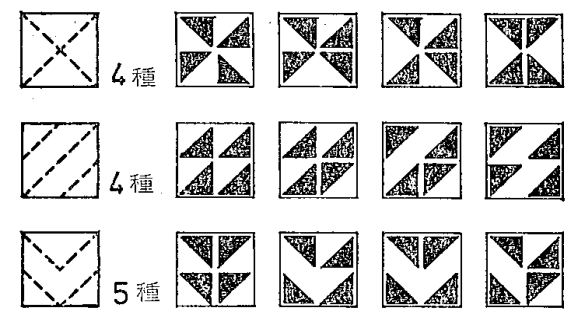

\section{7}

图一13 代表的パターン

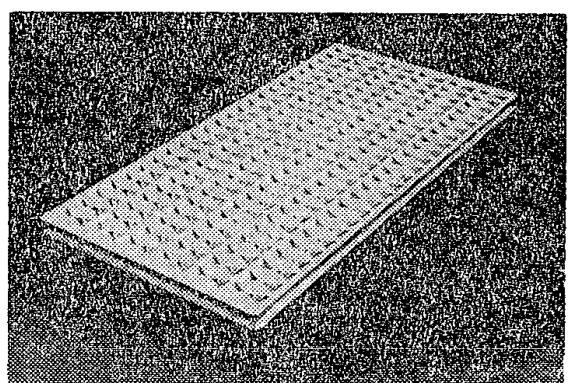

写真一3

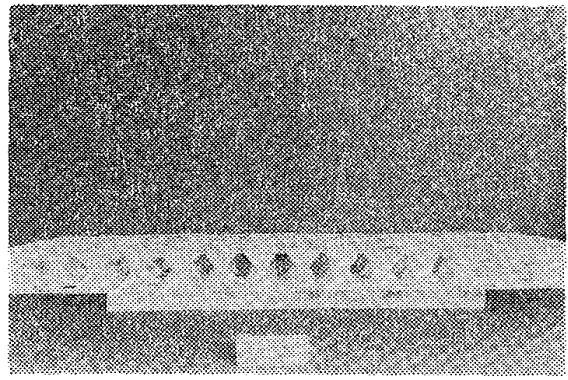

写真-4
次にこの 2 次ユニットの連続のさせ方を若える。これ についてむ無限に存在しらるが，ウェブの通り方がこれ を連続させることによって変化しないようにするという 条件を加え次に示す 4 種とした。
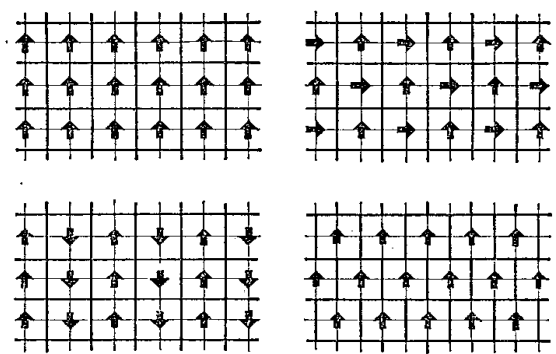

図一14 基本ユニットの配列

（2） D. 型について

このタイプむ前のタイプと同じように考えることが出 来るので前半は省略し後半について述べる。

2 次コニットはこの場合，折り曲げ線に直角方法の断 面を取りウェブがどのように通っているか見ることと， また，折り曲げられたウェブが折り曲げ線と同じ方向に どのよらに遭続して行くかを見ることの 2 通りが必要と なる。

まず「折り曲げ線に直角方向」に着目すると大きく 3 種に分けられる。

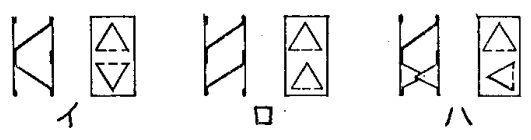

図一15 折り地げ線に直角方向

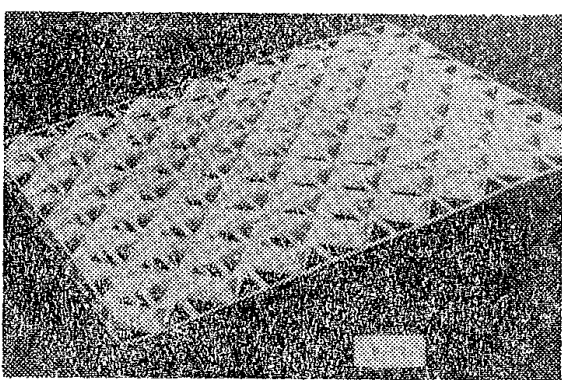

写壹-5

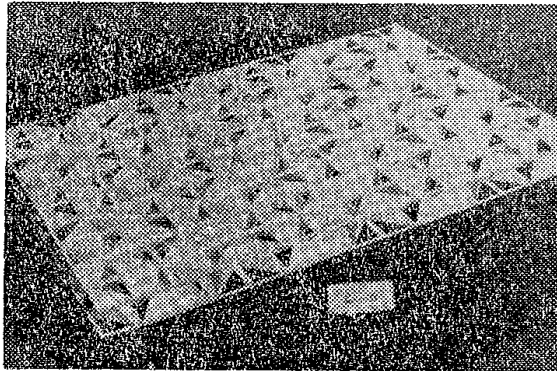

写真-6

（イ）はウェブがトラス状に連続していくもの，(口)は 一方向に向って並んでいるもの（ハ）は折り曲げ線が一 方向に向いていないものである。

又「折り曲げ線と同方向」の連続性に関してもやはり 3 種に分けられる。 


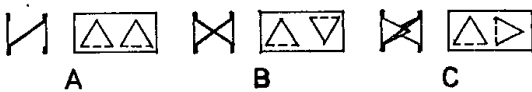

図一16 折り曲げ線と同方向

（A）はウェブが同一平面上 (同方向) に並ぶもの，(B) は交互に並んでウェブが交差するもの，(C) は（ハ）と 同じものである。

ここで以上 2 通りの見方を組み合わせると，下図に示 す 5 種のパターンが得られる。

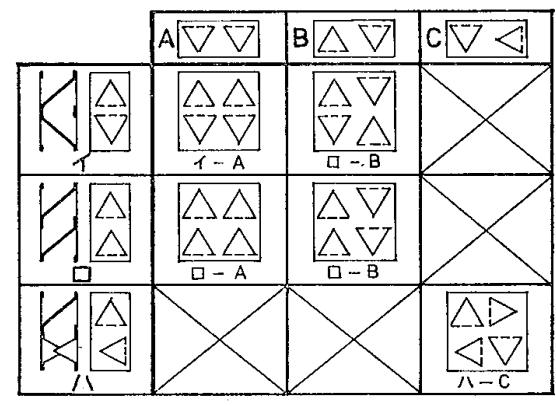

図-17 代表的パターン

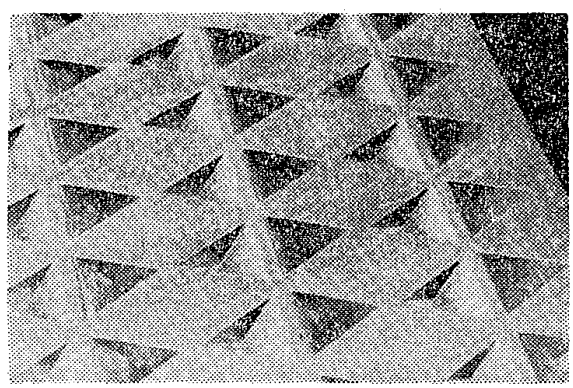

写真—7

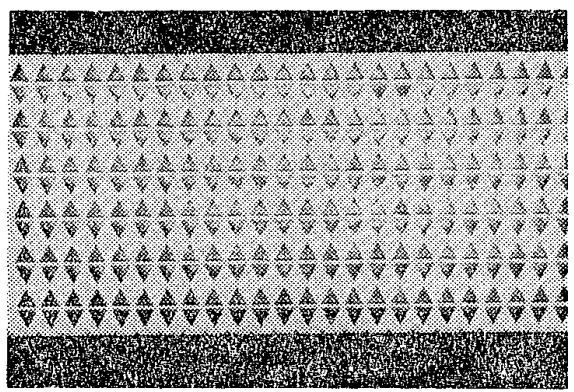

写罂—8

図一17 の内，[ロ-A]はすべてりウェブが一方向に向 いているため，実際は転倒（つぶれ）してほまい，圧縮 （曲げ）に剂しては弱いことが明白である。

\section{（3） $\triangle$ 型について}

このタイプは（1） (2) のタイプとは異っている。こ のひし形を並べていけばやはり無数のパターンが出来る わけだが，実際に規則性のあるパターンと言うことにな ると非常に数が少なく，以下に示す 2 種に決まる。
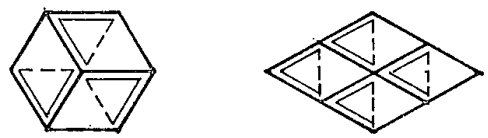

图一18 ひし形基本ユニット
さらに付け加えると，このタイプの 1 次ユニットを用 いることの出来るパネルは, その外形からして非常に特 殊な正六角形やひし形等の場合に限られる。

\section{9. 考察}

前記の発想に基づき開発したパネルの構法システムを 原理的に一貫したシステムで計画出来，一つの発想から 開発に至る展開の方法論が提案された。

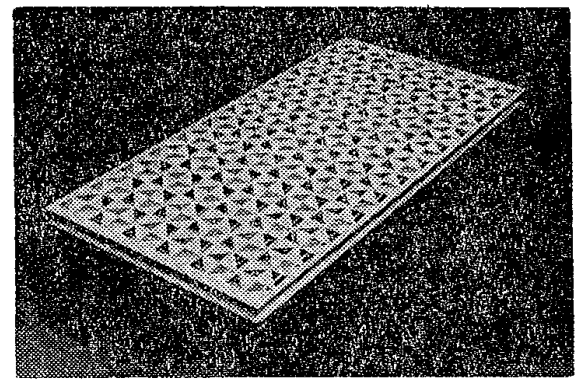

写真一9

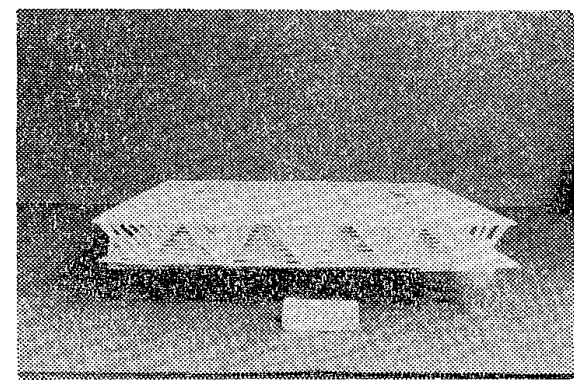

写真一 10

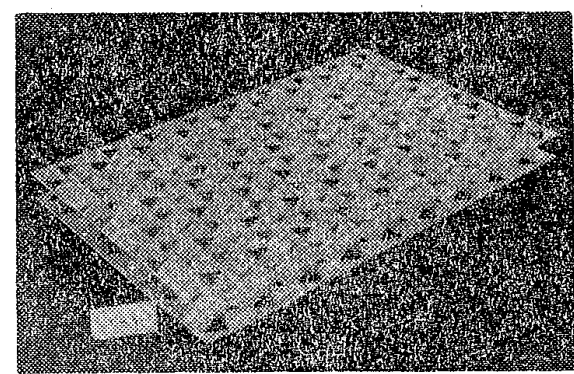

写基-11

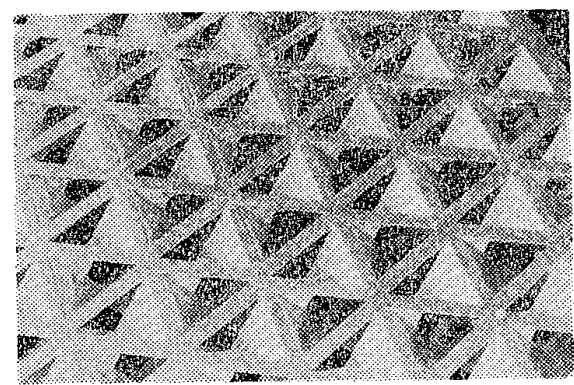

写园-12

本研究の結果得られたパターンを用いたパネルを紙に より試作することにより，十分実睍可能であることが判 明した。と同時に，金属板 (亜鎑鉄板) に打いても，写 真のように十分製作可能な見通しがついた。このように 作出されたパネルの強度及び強度比較については, 今後 の研究に残された課題である。当研究室で製作した合成 紙（盐ビベース）による実験の結果では，従来のパネル 
と比較して，より軽量で，耐力の大きいパネルになるこ とが定性的に証明できた。（尚，強度実験については，い ずれ報告する機会があるであろら。)

本研究はパネルのみに着目した研究であるため，建築 への適用については今後の課題であるが，用途としては 次のようなむのが考えられる。

1. 加工して使用の場合

プレファブ住宅等における, 床, 壁, 天井, 屋根等に 使用。（当然, 性能調整する意味で, 断熱材, 吸音材, 遮 音材等を挿入し，表面に仕上げをほどこすことを想定し ている。)
2.そのまま使用の場合

ルーバ一的利用, スクリーン的利用, 雨户用, 天井用 としての利用などが考えられる。

本研究の進展によっては従来問題であった面部品の生 産技術に妨ける飛躍的な発展が期待できる。

注 1）伊藤邦明「プレス成形による金属整立体トラス版の研 究一七の 1一」大会学術講演梗概集, 昭 46.10 参照。

注 2)ここでいう原理とは, 本パホルシステムに晾りるもの を意味する。

注 3）「1次ユニット」とは，1つの接合により成立するも のをいう。これは原子に䇾えられる。

注 4)「2次ユニット」とは，1次ユニットが数個集まって 構成するもの。これは分子に譬えられる。

\section{SYNOPSIS}

UDC : 69.051 .1

\section{THE PANEL WHICH IS CONSTRUCTED BY TWO SHEETS}

by Dr. YOSUKE IGUCHI, Prof. of Science Univ. of Tokyo and KIYOTAIKE SUZUKI, HIROTAKA ENDO, Graduate Students of Science Univ. of Tokyo, Members of A.I.J.

On industrialized building, panels are the most important and largest quantity parts. But they have many problems. For example wooden panel's problem is "haveing many kinds of parts" and "complicated assemble".

So we thought problems of industrialized panel. We looked out the object of development the planning condition. By them, we created the idea the panel is constructed by two sheets. Next, we made clear the principle of the idea, and by the principle we designned the panels, which is suited to the object and the condition. And then we developed the variety of the panel by the method of "Building Construction Method Planning".

\section{CONTENTS}

1. Purpose of the study

2. Object of development

3. Planning condition

4. Principle of panel construction

5. Notation

6. Single unit's way of thinking

7. Single units

8. Pattern

9. Consideration 